\title{
Presence of the alien species Godiva quadricolor (Barnard, 1927) (Gastropoda Nudibranchia Facelinidae) along the coast of eastern Sicily
}

\author{
Andrea Lombardo \& Giuliana Marletta
}

Department of Biological, Geological and Environmental Sciences - Section of Animal Biology, University of Catania, via Androne 81, 95124 Catania, Italy

Corresponding author, e-mail: andylombardo94@gmail.com

\begin{abstract}
This work explores the second report of the alien nudibranch Godiva quadricolor (Barnard, 1927) (Gastropoda Nudibranchia Facelinidae) in eastern Sicily (Italy). Previously, this species has been found only in the area of Faro Lake (Messina), where now there is a significant population. The specimen here reported was sighted while diving in Santa Maria La Scala (Acireale, Catania) near a fresh water source. In fact, as it has been claimed by other authors, there is a strong correlation between this species and the brackish water areas. This work argues that this specimen has been brought to this area either by the Strait of Messina currents or by fishing boats, which dock at a small port in the study area. Since this is a species which easily adapts to different environmental conditions and feeds on other nudibranchs, G. quadricolor propagation could be a great threat to indigenous biodiversity.
\end{abstract}

KEY WORDS Alien species; Gastropoda; Godiva quadricolor; nudibranch; Sicily.

Received 06.03.2019; accepted 24.05.2019; published online 24.06.2019

\section{INTRODUCTION}

Godiva quadricolor (Barnard, 1927) is a nudibranch (Gastropoda Nudibranchia Facelinidae) discovered in the area of False Bay, in South Africa. During the last century this species has been found in different tropical and temperate waters of the world: Mozambique (Macnae, 1954), Tanzania (Willan, 2004), Ghana (Edmunds, 1977), Australia (Willan, 1987), Morocco (Atlantic Ocean) and the Strait of Gibraltar (Cervera et al., 2010). In the Mediterranean Sea, apart from the Strait of Gibraltar (Bay of Algeciras), this nudibranch has been reported also along the coasts of France (Étang de Thau) (Crocetta \& Malegue in
Gerovasileiou et al., 2017) and in several coasts of Italy: in the Fusaro lake in the Gulf of Naples (Cattaneo-Vietti et al., 1990), in the Sabaudia lake near Latina (Macali et al., 2013), at Noli in the Ligurian Sea (Betti et al., 2015), in the North Adriatic, among the coasts of Ravenna (Zenetos et al., 2016), and in the Faro lake in Sicily (Furfaro et al., 2018). In the coasts of Noli and Ravenna this species appeared only temporary (Betti et al., 2015; Zenetos et al., 2016), while in the lakes of Fusaro and Faro G. quadricolor still forms stable populations (Villani \& Martinez, 1993; Furfaro et al., 2018). In both cases, the lakes are connected to the sea and consequently these populations live in brackish water areas. 
G. quadricolor is a marine species which can settle in brackish water areas and adapt to a great variety of environmental conditions, especially for what concerns temperature and salinity. This organism lives in both temperate and tropical waters, proving that it is a euriecia species. Moreover, since this species has been detected in anthropized coasts with a significant marine traffic, it has been claimed that the alien G. quadricolor was brought to the Mediterranean Sea by ballast waters (Willan, 2004; Cervera et al., 2010). Native of the Indian Ocean and now common also in South African coasts, this species has penetrated in the Mediterranean Sea through either the Strait of Gibraltar or the Suez Channel, because of surface water warming (Trainito \& Doneddu, 2014; Betti et al., 2015).

\section{MATERIAL AND METHODS}

The Timpa is a big coastal slope in the Ionic coast of Sicily (Italy), which belongs to the town of Acireale. It hosts a rich natural heritage, both marine and terrestrial. In particular, the specimen has been found in the area of a spring called "Testa dell'acqua", which used to feed a XVI century mill, in Santa Maria La Scala $\left(37^{\circ} 37^{\prime} 2^{\prime \prime} \mathrm{N}, 1^{\circ}\right.$ $\left.10^{\prime} 20^{\prime \prime} \mathrm{E}\right)$. In general, the area of Timpa shows several springs that determine the flow of fresh water from Mount Etna to the sea (Ferrara, 1977; Catra et al., 2006). The sea floor where the animal was found is characterized by boulders and rocks of variable size, formed after the erosive activity of the sea.

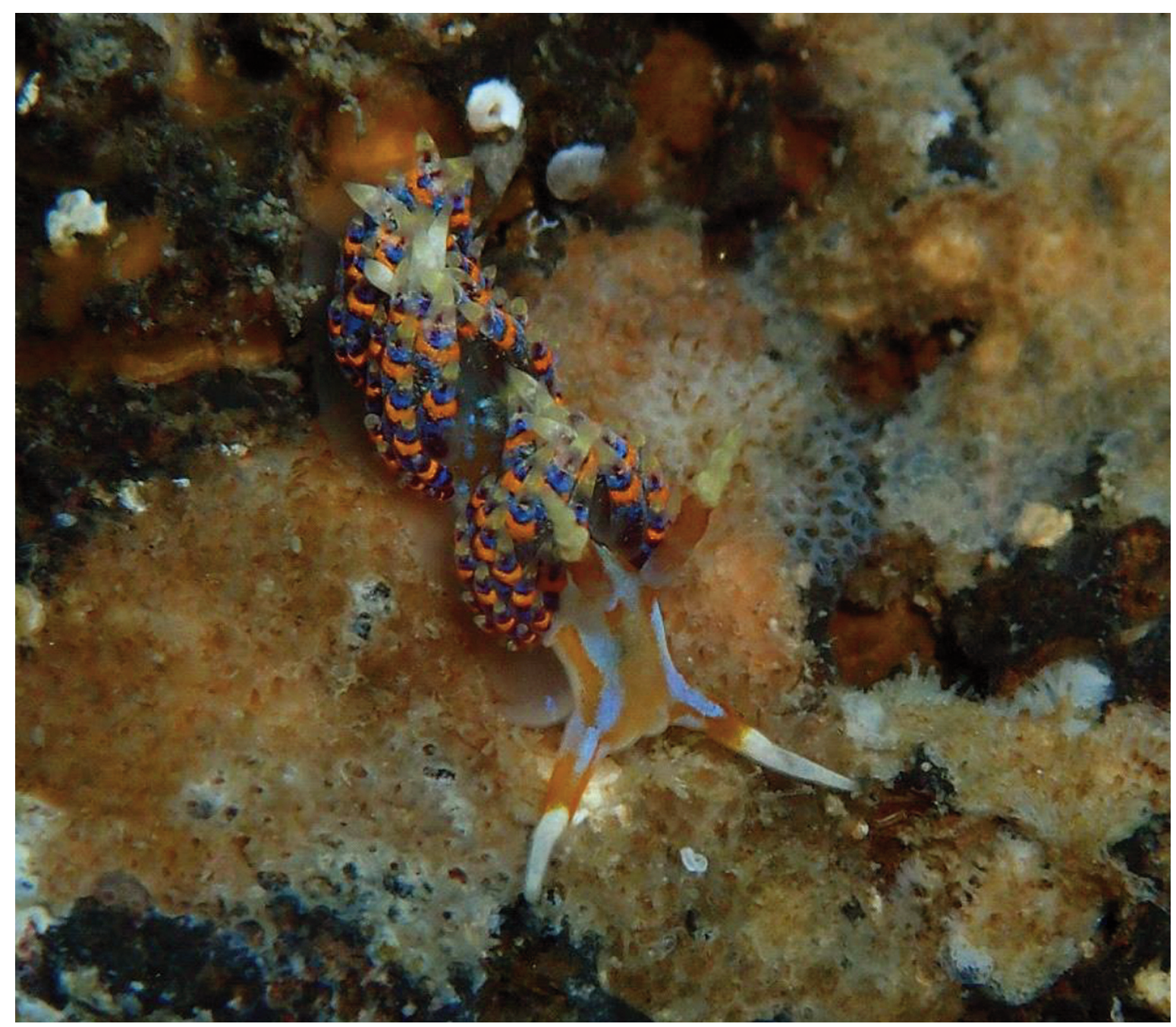

Figure 1. The Godiva quadricolor specimen found in Santa Maria La Scala (Sicily, Italy). Photo by A. Lombardo. 
The G. quadricolor specimen was photographed with an Olympus TG4 underwater camera.

\section{RESULTS}

On 23rd November 2018, a small G. quadricolor specimen was found under a stone at $7 \mathrm{mt}$ depth, while diving in Santa Maria La Scala (Acireale, Catania, Italy). The animal was photographed and identified "in vivo" (Fig. 1). It showed all the external morphological features reported in Bernard's original description (1927): wrinkled rhinophores; a white line going from the base of each rhinophores to the base of its corresponding oral tentacles; a slender body with a predominance of white; cerata with a specific pattern (blue ring, brown ring, orange ring, brown ring, blue ring, etc.); white-cream upper parts. As regards its behaviour, the nudibranch avoided the sunlight in search of darker areas: this could demonstrate that it is a shade-lover.

\section{CONCLUSIONS}

This is the second report in Sicily, after that in Faro Lake (Furfaro et al., 2018). Since in the area of Messina there is a significant population of $G$. quadricolor (Furfaro et al., 2018), this work claims that the found specimen could have been taken in veliger stage through the Strait of Messina currents. Otherwise, since Santa Maria La Scala hosts a small port, that veliger of G. quadricolor could have travelled attached to the keel of some fishing boats. Moreover, the specimen was in a coastal area, like that of Noli (Betti et al., 2015), but influenced by fresh waters (Ferrara, 1977; Catra et al., 2006), as it has been previously highlighted.

This finding confirms the great adaptability of this species to different environmental conditions, especially for what concerns temperature and salinity. Moreover, it testifies that this species is spreading quickly in the Mediterranean Sea, where the first report in Fusaro Lake dates back to 1985 (Cattaneo-Vietti et al., 1990). Since it is a voracious nudibranchs predator (Gosliner, 1987), it could become a threat to indigenous nudibranchs fauna and a danger to biodiversity.

\section{REFERENCES}

Barnard K. H., 1927. South African nudibranch Mollusca, with descriptions of new species, and a note on some specimens from Tristan d'Acunha. Annals of the South African Museum, 2: 171-215.

Betti F., Cattaneo-Vietti R. \& Bava S., 2015. Northernmost record of Godiva quadricolor (Gastropoda: Nudibranchia) in the SCI "Fondali Noli-Bergeggi" (Ligurian Sea). Marine Biodiversity Record, 8: 1-4. https://doi.org/10.1017/S1755267215000032

Catra M., Giaccone T., Giardina S. \& Nicastro A., 2006. Il patrimonio naturale marino bentonico della Timpa di Acireale (Catania). Bollettino dell'Accademia Gioenia di Scienze Naturali, 39: 129-158.

Cattaneo-Vietti R., Chemello R. \& Giannuzzi-Savelli R., 1990. Atlas of Mediterranean nudibranchs. La Conchiglia., Rome, 264 pp.

Cervera J.L., Tamsouri N., Moukrim A. \& Villani G., 2010. New records of two alien opisthobranch molluscs from the north-eastern Atlantic: Polycera hedgpethi and Godiva quadricolor. Marine Biodiversity Records, 3: 1-4. https://doi.org/10.1017/S1755267 210000102

Edmunds M., 1977. Larval development, oceanic currents, and origins of the opisthobranch fauna of Ghana. Journal of Molluscan Studies, 43: 301-308. https: //doi.org/10.1093/oxfordjournals.mollus.a065385

Ferrara V., 1977. Aspetti idrogeologici del territorio del comune di Acireale. Memorie e rendiconti dell'Accademia di Scienze, Lettere e Belle Arti degli Zelanti e dei Dafnei, Acireale, Serie II, 7: 455-488.

Furfaro G., De Matteo S., Mariottini P. \& Giacobbe S., 2018. Ecological notes of the alien species Godiva quadricolor (Gastropoda: Nudibranchia) occurring in Faro Lake (Italy). Journal of Natural History, 52: 645-657. https://doi.org/10.1080/00222933.2018.14 45788

Gerovasileiou V., Akel E., Akyol O., Alongi G., Azevedo F., Babali N., Bakiu R., Bariche M., Bennoui A., Castriota L., Chintiroglou C.C., Crocetta F., Deidun A., Galinou-Mitsoudi S., Giovos I., Gökoğlu M., Golemaj A., Hadjioannou L., Hartingerova J., Insacco G., Katsanevakis S., Kleitou P., Korun J., Lipej L., Malegue M., Michailidis N., Mouzai Tifoura A., Ovalis P., Petović S., Piraino S., Rizkalla S.I., Rousou M., Savva I., Şen H., Spinelli A., Vougioukalou K.G., Xharahi E., Zava B. \& Zenetos A., 2017. New Mediterranean Biodiversity Records (July, 2017). Mediterranean Marine Science, 18: 355-384. http:// dx.doi.org/10.12681/mms.2068

Gosliner T.M., 1987. Nudibranchs of Southern Africa. A guide to opisthobranch molluscs of Southern Africa. Sea Challengers and Jeff Hamman Publications, Monterey, 136 pp. 
Macali A., Conde A., Smriglio C., Mariottini P. \& Crocetta F., 2013. The evolution of the molluscan biota of Sabaudia Lake: a matter of human history. Scientia Marina, 77: 649-662. https://doi.org/10.3989/scimar. $03858.05 \mathrm{M}$

Macnae W., 1954. On some eolidacean nudibranchiate molluscs from South Africa. Annals of the Natal Museum, 13: 1-50.

Trainito E. \& Doneddu M., 2014. Nudibranchi del Mediterraneo. Il Castello, Cornaredo, 192 pp.

Villani G. \& Martinez E., 1993. Some observations on the opisthobranch fauna from the Fusaro Lake, a brackish-water lagoon near Naples. Bollettino Malacologico, 29: 201-209.

Willan R.C., 1987. Phylogenetic systematics and zoogeography of Australian nudibranchs: 1 . Presence of the aeolid Godiva quadricolor (Barnard) in Western Australia. Journal of the Malacological Society of Australia, 8: 71-85. https://doi.org/10.1080/008529 88.1987.10673993

Willan R.C., 2004. Godiva quadricolor (Barnard, 1927) (Nudibranchia: Facelinidae) spreads into southern Queensland. Beagle: Records of the Museums and Art Galleries of the Northern Territory, 20: 31-36.

Zenetos A., Mačić V., Jaklin A., Lipej L., Poursanidis D., Cattaneo-Vietti R., Beqiraj S., Betti F., Poloniato D., Kashta L., Katsanevakis S. \& Crocetta F., 2016. Adriatic 'opisthobranchs' (Gastropoda, Heterobranchia): shedding light on biodiversity issues. Marine Ecology 37: 1239-1255. https://doi.org/10.1111/maec. 12306 